\title{
Pancreatic Development and Adult Diabetes
}

\author{
DAVID J. HILL AND BERTRAND DUVILLIÉ \\ Lawson Research Institute, St. Joseph's Health Centre, London, Ontario N6A 4V2, Canada; and Departments \\ of Physiology, Medicine, and Paediatrics, University of Western Ontario, London, Ontario N6A 5A5, Canada
}

\begin{tabular}{|c|c|}
\hline \multicolumn{2}{|c|}{ ABSTRACT } \\
\hline $\begin{array}{l}\text { Low birth weight is an important risk factor for type } 2 \\
\text { diabetes in later life. Maturity-onset diabetes of the young has } \\
\text { been linked to genetic sequence abnormalities in transcription } \\
\text { factors known to be involved in endocrine pancreatic develop- } \\
\text { ment. These observations suggest that both the maternal envi- } \\
\text { ronment and the fetal genome can influence the number and/or } \\
\text { function of pancreatic } \beta \text { cells in early life, and that this has } \\
\text { life-long implications for postnatal diabetes. This article reviews } \\
\text { the evidence that suggests that } \beta \text { cells derive from a neogenic } \\
\text { process within the pancreatic ductal epithelium, controlled by } \\
\text { specific transcription factors and locally acting peptide growth } \\
\text { factors. In rodents, many of the fetal phenotypes of } \beta \text { cells are } \\
\text { destroyed during neonatal life in a developmental apoptosis and } \\
\text { are replaced by a second wave of neogenesis. This results in } \\
\text { islets with insulin release characteristics suited to postnatal life. } \\
\text { The timing and amplitude of these ontological events are altered } \\
\text { by nutritional sufficiency, and this may be mediated by changes } \\
\text { in pancreatic growth factor expression, particularly of the IGF }\end{array}$ & $\begin{array}{l}\text { axis. Because } \beta \text {-cell plasticity after the perinatal period is lim- } \\
\text { ited, a dysfunctional programming of } \beta \text {-cell ontogeny may } \\
\text { present a long-term risk factor for glucose intolerance and type } 2 \\
\text { diabetes. This critical window of pancreatic development is } \\
\text { likely to occur in third trimester of human development. (Pediatr } \\
\text { Res 48: 269-274, 2000) } \\
\qquad \text { Abbreviations } \\
\text { MODY, maturity-onset diabetes of the young } \\
\text { IUGR, intrauterine growth restriction } \\
\text { Shh, Sonic hedgehog gene } \\
\text { PP, pancreatic peptide } \\
\text { FGF, fibroblast growth factor } \\
\text { DTA, diphtheria toxin } \\
\text { HNF, hepatocyte nuclear factor } \\
\text { PTF1, pancreatic transcription factor } 1 \\
\text { VEGF, vascular endothelial growth factor }\end{array}$ \\
\hline
\end{tabular}

\section{INTRAUTERINE GROWTH RESTRICTION AND GLUCOSE HOMEOSTASIS IN ADULTS}

IUGR is a risk factor for both perinatal disease and diseases of later life. Barker et al. showed that a strong inverse correlation exists between mortality from cardiovascular disease below age 65 and birth weight (1). Similarly, the relative risk for prevalence of syndrome $\mathrm{X}$, consisting of type 2 diabetes, hypertension and hyperlipidemia, is 18-fold higher in males born $<2.5 \mathrm{~kg}$ compared with those $>4 \mathrm{~kg}(1,2)$. The at-risk individuals were thin at birth with a low ponderal index. Impaired glucose tolerance can be detected as early as $7 \mathrm{y}$ of age in children who at birth had low weight and were thin (3). This implies that a programming of the metabolic axis can occur in early life, which is modulated by the

Received January 12, 2000; accepted April 6, 2000.

Correspondence: D.J. Hill, M.D., Lawson Research Institute, St. Joseph's Health Centre, 268 Grosvenor Street, London, Ontario, Canada, N6A 4V2.

Those studies performed by the authors were supported by the Medical Research Council of Canada, the Juvenile Diabetes Foundation International, and the Canadian Diabetes Association. intrauterine environment. For type 2 diabetes this may result from an altered development and insulin-secreting capacity of the endocrine pancreas, or by altered insulin sensitivity of target tissues. It is possible that perturbations of prenatal growth may lead to inappropriate $\beta$-cell ontogeny and result in a population of $\beta$ cells qualitatively ill suited to subsequently manage metabolic stress. A reduced availability of insulin prenatally is a major contributor to IUGR. This can be experimentally demonstrated in extreme form using insulin gene knockout mice (4) whose birth weight was $25 \%$ less than heterozygote littermates at birth; it is also demonstrated by the severe growth retardation of human infants with pancreatic agenesis (5). Insulin deficiency may result from either genetic mutations in transcription factors active during $\beta$-cell formation, or from altered expression of transcription factors and peptide growth factors due to environmental influences in utero.

Intrauterine growth restriction in rat or man results in a reduced population of pancreatic $\beta$ cells at birth $(6,7)$. Maternal calorie restriction by $50 \%$ in rat from d 15 of gestation until term showed that $\beta$-cell mass was reduced in the newborn due 
to a reduction in the number of islets (8). If normal diet was restored at birth, the $\beta$-cell mass returned to that of controls by weaning. However, continuation of energy restriction during neonatal life leads to irreversible changes in $\beta$-cell mass. A reduction of dietary protein to $8 \%$ throughout gestation caused relative growth restriction at birth with reduced $\beta$-cell mass and islet cell size $(9,10)$. Again, if nutritional restriction was lifted at birth, the islet morphology recovered, but if extended to weaning the changes were irreversible. Such animals are susceptible to glucose intolerance in later life (10). These models show a strong effect of maternal environment on fetal islet development, but also that the neonatal period is a time of islet plasticity that will have life-long consequences for glucose homeostasis.

\section{ONTOGENY OF THE ENDOCRINE PANCREAS}

The pancreas arises from embryonic mid-gut endoderm. In the mouse, the dorsal pancreatic bud appears at embryonic (E) 9.5 closely followed by the ventral bud, and these fuse at embryonic d E16-17 (11). As each bud grows it forms highly branched structures and the acini and ducts become distinguishable at d E14.5. Endocrine cells can be found from the earliest stages of bud development and by d E15.5 make up $10 \%$ of the pancreas. Initially, they are seen as individual cells or small clusters close to the pancreatic ducts, and only form as mature islets in the final few days of gestation. This is achieved by early third trimester in the human fetus. The growth and cyto-differentiation of the pancreas depends on mesenchymalepithelial interaction. Pancreatic mesenchyme accumulates around the dorsal gut epithelium and induces pancreatic bud formation and branching (12-15). The earliest signal may be derived from the notochord, whereby notochordal repression of endodermal Shh expression permits pancreas development (16-18). Hebrok et al. (17) found in the chick that activin- $\beta \mathrm{B}$ and fibroblast growth factor-2 (FGF-2) are notochord factors that can repress endodermal $S h h$ and thereby permit expression of pancreas genes, including $P d x-1$ and insulin. The earliest morphogenetic signaling in pancreas formation therefore depends on interplay between peptide growth factors and tissue transcription factors, an interaction that is apparent throughout islet formation.

Teitelman et al. (19) suggested that the precursor cells of the endocrine pancreas coexpress insulin, glucagon, and also the neuronal proteins tyrosine hydroxylase and neuropeptide $\mathrm{Y}$. These proteins were first detectable by immunocytochemistry on d E9.5 in mouse, whereas PP was detected only at birth. However, Herrera et al. (20) found PP immunopositive cells as early as d E9.5. The expression of the A chain of the DTA placed under the control of elastase I in transgenic mice, thus killing cells expressing elastase 1 , produced animals with a rudimentary pancreas and only a few ductal cells and islets of Langerhans. Elastase I is normally expressed in the exocrine tissue. This suggested that the early disruption of the elastaseexpressing cells dramatically affected endocrine pancreatic development. Herrera et al. (21) produced transgenic mice expressing the DTA gene placed under the control of the insulin, glucagon, somatostatin, or PP promoters. They dem- onstrated that only the PP promoter decreased endocrine cell type number within the islets, suggesting that the PP cells might be the endocrine precursor cells.

The differentiation of the endocrine pancreas is ongoing at birth in rodent species. Neogenesis of islets continues through neonatal life but ceases shortly after weaning (22). In the rat fetus the cellular area staining immunopositively for insulin increases twofold over $2 \mathrm{~d}$ just before term, deriving both from $\beta$-cell replication and ductular neogenesis (23). Conversely, the rate of mitosis in adult pancreatic $\beta$ cells is normally low (24). This fundamental change in cell phenotype has been linked to a transient wave of apoptosis that occurs in neonatal rat islets 2 wk after birth (25-27), and the replacement of these lost $\beta$ cells with new islets by ductular neogenesis. This partial replacement of $\beta$ cells may generate a cell population suited to metabolic control in later adult life. Because the final population of $\beta$ cells will have only limited potential for regeneration in the adult animal, any aberrant apoptotic deletion of fetaltype cells, or the parallel neogenesis of adult-type islets, is likely to alter the ability of the animal to deal with metabolic stress. The mechanisms leading to such cellular pathologies are likely to involve an altered expression of transcription and/or growth factors.

The development of ductal epithelial cells into an endocrine lineage, and ultimately into $\beta$ cells, is likely to involve a specific sequence of expression of transcription factors, interlinked with locally acting growth factor signals. A fundamental branch point is the progression of a pluripotential epithelial cell to either the endocrine or exocrine lineage (Fig. 1). One of the most important transcription factors identified so far for the endocrine lineage is Pdx-1, also known as STF-1, IDX-1, or IPF-1 (28). In animals with a targeted deletion of $P d x-1$, pancreatic buds form but no further differentiation or morphogenesis occurs (29). Expression of $P d x-1$ in undifferentiated ductal epithelium is associated with the glucose transporter GLUT 2, which by fetal d 15 in the rat has been lost from acinar cells, but is retained by developing $\beta$ cells. Pdx-1 therefore appears to have a dual role of an inducer of an early endocrine cell lineage from ductal epithelial cells, and in the maturation of $\beta$ cells and the control of insulin gene expression. A single deletion of a nucleotide in man leads to the complete agenesis of the pancreas (5). Pdx-1 expression is directed by at least two other nuclear transcription factors, HNF-3 $\beta$ and BETA-2/NeuroD (28). Conversely, PTF1 is able to transactivate the $5^{\prime}$ regions of genes that are specifically expressed in the exocrine tissue. Mice carrying null mutations of the p48 sub-unit of PTF1 did not have any pancreas, although groups of endocrine cells were detected, notably in the spleen (30). This result shows that PTF1 is a key factor for exocrine development.

What then are the trophic signals that determine the choice of endocrine or exocrine lineage, and the expression of transcription factors such as Pdx-1 or PTF1? They are likely to include growth factors expressed within the pancreatic stroma adjacent to the ductal epithelium, such as FGF-7 and VEGF (Table 1). Systemic injection of FGF-7 into adult rats for up to 2 wk caused a rapid increase in DNA synthesis within the ductal epithelium, which was seen within $24 \mathrm{~h}$ (31). Pancreatic 


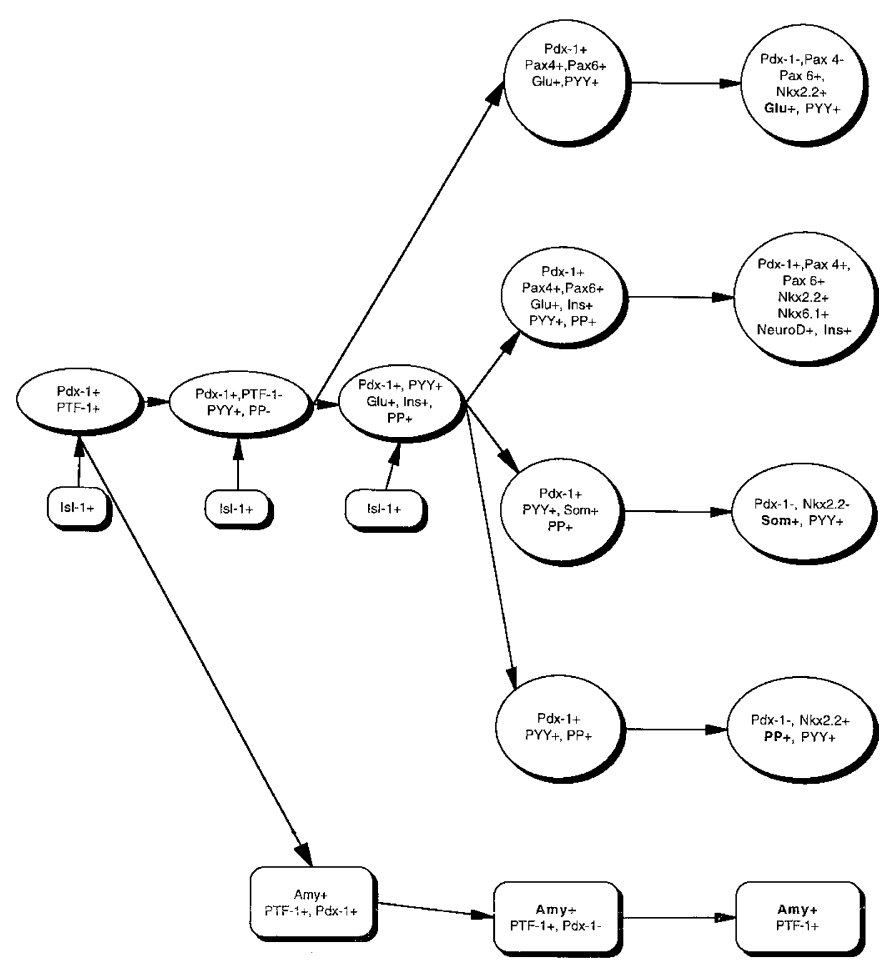

Figure 1. Schematic plan of the likely roles of transcription factors in the generation of pancreatic endocrine and exocrine lineages from a common stem cell within the developing pancreas. Early in development, precursor cells express transcription factors that commit them either to an endocrine $(P d x-1)$ or exocrine $(P T F-1)$ lineage. The discrimination depends in part on growth factor signals from surrounding mesenchyme under the control of transcription factors such as $I s l-1$. The early endocrine lineage expresses peptide YY $(\mathrm{PYY}+)$ and later, pancreatic polypeptide $(\mathrm{PP}+)$. Before the activation of the $\mathrm{PP}$ gene (PP-) a subpopulation of cells develops into glucagon-secreting $\alpha$ cells $(\mathrm{Glu}+)$. This involves a loss of $P d x-1$ expression $(P d x-1-)$ and the expression of the transcription factors Pax-6 and $N k x 2.2$. Precursor cells that continue to express PP and PYY develop into insulin-expressing $\beta$ cells with the transcription factor profile $P d x-1+, P a x 4+$ and $P a x 6+$, and $N k x 2.2+$, Nkx6.1+ and NeuroD+; somatostatin-expressing $\delta$ cells with the profile $P d x-1-$ and $N k x 2.2-$; and PP cells with a profile of $P d x-1-$ and $N k x 2.2+$. Insulin secretion from $\beta$ cells depends on the expression of the additional transcription factors $H N F-1 \alpha$ and $-4 \alpha$, together with $P d x$-1, mutations in each of which are associated with MODY. Exocrine cells remain $P T F-1+$, lose $P d x-1$ expression and synthesize amylase (Amy).

Table 1. Peptide growth factors involved in pancreatic $\beta$ cell development

\begin{tabular}{clc}
\hline Growth factor & \multicolumn{1}{c}{ Origin } & Biological actions \\
\hline FGF-7 & Pancreatic stroma & $\begin{array}{c}\text { Endocrine cell neogenesis } \\
\text { from ductal epithelium } \\
\text { Endocrine cell neogenesis } \\
\text { and angiogenesis }\end{array}$ \\
IGF-II & $\begin{array}{c}\text { Ductal epithelium and islet } \\
\text { endocrine cells }\end{array}$ & $\begin{array}{c}\text { Islet cell proliferation and } \\
\text { survival in the fetus } \\
\text { and neonate }\end{array}$ \\
IGF-I & Islet endocrine cells & $\begin{array}{c}\text { Islet cell proliferation and } \\
\text { survival in childhood }\end{array}$ \\
\hline
\end{tabular}

duct hyperplasia followed, but not a progression to increased numbers of endocrine cells. However, when FGF-7 was expressed within the embryonic liver of transgenic mice, pancreatic duct hyperplasia was seen with increased numbers of ductal cells containing immunoreactive insulin (32). VEGF is a potent mitogen for endothelial cells using two high-affinity tyrosine kinase-type receptors, Flt-1 and Flk-1. Flk-1 mRNA is expressed within RINm2F islet cells, as well as in fetal rat islets where VEGF is able to increase insulin content (33). In intact fetal rat pancreas, immunoreactive Flk-1 was localized to pancreatic ductal cells and vascular endothelium, suggesting that ductal cells may also be a target for VEGF action. VEGF was found to enhance ductal cell replication and insulin content, implying that a $\beta$-cell neogenesis was also occurring (34). In adult human islets and insulinomas, VEGF was localized to $\beta$ cells, whereas in the human fetus it was found within immature islets $(35,36)$. Although VEGF must be a prime candidate for initiating an angiogenic growth response in support of an increasing islet cell mass, it may also act directly as a mitogen and morphogen for ductal epithelial cells.

Once ductal epithelial cells have entered the endocrine lineage they become further differentiated into the separate endocrine cell types, a process controlled by the Pax transcription factors, of which Pax-4 and Pax- 6 are expressed in the developing pancreas (Fig. 1). In the early mouse embryo Pax-4 was detected in insulin-containing cells, and after birth remains restricted to the $\beta$ cells (37). Conversely, Pax-6 coexpressed with glucagon-containing cells, but after d E15.5 was found in all the endocrine cells (38). Deletion of Pax-4 caused a complete loss of pancreatic $\beta$ cells and $\delta$ cells, but an increased number of $\alpha$ cells. Conversely, functional deletion of the Pax-6 gene in mouse decreases the presence of all four endocrine cell types in the pancreas, with the presence of $\alpha$ cells being totally abolished $(39,40)$. Pax- 6 has been shown to transactivate both the glucagon and insulin genes promoters. Mice lacking both Pax-4 and Pax-6 failed to develop any mature endocrine cells in the pancreas (39). Pax-4 and Pax-6 appear to be important in distinguishing the $\alpha$ cell lineage from $\beta$ and $\delta$ cells, but act in parallel, not in series with Pdx-1 expression. Other transcription factors such as Nkx 2.2, Nkx 6.1, and Isl-1 also play defined roles, as outlined in Figure 1.

The ongoing proliferation and developmental differentiation of $\beta$ cells, once formed, is highly dependent on the expression of the IGF within the islets (Table 1). Multiple studies indicate that IGF potentiate $\beta$-cell growth, maturation, and function, and are expressed by $\beta$ cells throughout life. IGF-II mRNA is greatest in the fetal pancreas, and declines during the neonatal period $(41,42)$. Using in situ hybridization, IGF-II mRNA was shown to be expressed within islet cells in the fetus and neonate, and also in focal clusters of ductal epithelial cells. Levels of IGF-II mRNA in the human fetal pancreas are 100 -fold greater than those for IGF-I (43). Exogenous IGF-I or -II promote increased DNA synthesis by isolated fetal or neonatal rat islets $(44,45)$, and isolated $\alpha$ and $\beta$ cells from rat islets contain the high-affinity type 1 IGF signaling receptor (46). Using a transgenic mouse model we showed that an overexpression of IGF-II caused a four- to fivefold increase in the mean islet size at birth, affecting all endocrine cell types, but that the total number of mature islets was not altered (47). This implies that, in vivo, IGF-II functions as a growth factor for existing islet cells but does not promote islet neogenesis.

The wave of developmental $\beta$-cell apoptosis in the neonatal rat seen 2 wk after birth (27) coincides temporally with a diminished pancreatic expression of IGF-II within islets. A 
nadir in total IGF availability may therefore exist in pancreas when apoptosis is transiently high. IGF inhibit apoptosis in a wide range of cell types in vitro $(48,49)$, and it has been demonstrated that endogenous IGF-II within isolated neonatal rat islets was able to protect them from cytokine-induced apoptosis (27). This protection was lost by weaning when islets no longer expressed IGF-II, but could be replaced with exogenous IGF-II. Further functional proof that changes in IGF-II availability provoke developmental $\beta$-cell apoptosis in the rat was obtained from a transgenic mouse model overexpressing IGF-II in skin, leading to increased circulating levels that did not fall postnatally. In these animals the neonatal wave of $\beta$-cell apoptosis is suppressed. There is therefore substantive data to show that IGF-II has a role in the homeostasis of $\beta$-cell mass in early life, but is predominantly a growth and survival factor for existing islet cells.

\section{ABNORMAL EXPRESSION OF TRANSCRIPTION AND GROWTH FACTORS LEADS TO ALTERED B-CELL MASS AND FUNCTION, AND DIABETES}

The consequences of a functional absence of a transcription factor can be dramatic as a single deletion in $P d x-1$ led to the complete agenesis of the human fetal pancreas (5). Several other cases of pancreatic agenesis have been described in the human infant, but no genetic disorder was established. The phenotype is characterized by severe growth retardation with term birth weights of 1.7-1.9 kg, poor muscle mass, and an absence of adiposity, which can be directly related to the lack of insulin (50-53).

MODY, a form of type 2 diabetes, is a monogenic disease with autosomal dominant inheritance, and is characterized by an early onset (childhood, adolescence, or young adulthood) of failure of insulin secretion (54). The clinical phenotype is very variable, perhaps attributed to genetic heterogeneity. The known genes that are involved in MODY are hepatocyte nuclear factor $4 \alpha(H N F-4 \alpha)$ (MODY 1) (55), glucokinase (MODY 2) (56, 57), $H N F-1 \alpha$ (MODY 3) (58), and $P d x-1$ (MODY 4) (59). MODY 4 was observed in patients carrying a heterozygous mutation in $P d x-1$. The resulting phenotype differed very much between individuals, some being normal, others being glucose intolerant, suggesting that the penetrance of this mutation was not complete. Targeted disruption of the mouse $P d x-1$ gene in $\beta$ cells alone resulted in those animals progressively becoming diabetic with age (60), showing that $\mathrm{Pdx}-1$ is required to maintain the $\beta$-cell identity by positively regulating insulin and islet amyloid polypeptide expression, and by repressing glucagon expression. The expression of the HNF factors were first found in the liver, but a role in the pancreas now also seems likely, as in MODY 3 there is an impaired insulin secretion (61). Mice lacking the $H N F-1 \alpha$ gene showed inadequate insulin secretion and $\beta$-cell intracellular calcium responses after stimulation with nutrient secretagogues such as glucose (62). A family of patients with MODY 1 has been described with mutations in $H N F-4 \alpha$ who developed diabetes requiring insulin therapy in $30 \%$ of cases (54). Such patients demonstrate primary defects in $\beta$-cell insulin-release mechanisms $(63,64)$.
An abnormal $\beta$-cell mass may also result from altered expression of structurally intact transcription factors because of environmental pressures. $P d x-1$ gene expression within isletlike cell clusters was down regulated by hyperglycaemia (65), as was $H N F-3 \beta$ but less so BETA-2 (66), and by fatty acids (66). Low glucose levels will also limit $P d x$-1 expression in $\beta$ cells (68). Partial pancreatectomy in the juvenile rat leads to a reduction in the expression of Pdx-1, GLUT 2, and insulin mRNA (69), most likely due to the associated hyperglycemia.

An altered expression of IGF or IGF binding protein (BP) associated with IUGR due to neonatal undernutrition may severely alter $\beta$-cell ontogeny after birth, leading to a population of $\beta$ cells less than optimally equipped to handle metabolic challenge in later life. IUGR in rats, induced either by maternal fasting (70), maternal diabetes (71), or restricted uteroplacental blood flow (72), is associated with reduced circulating IGF levels, pancreatic weights, and pancreatic insulin contents. Parallel findings exist in human infants following IUGR (73). A low-protein diet causes an altered $\beta$-cell ontogeny in the fetal and neonatal rat in which the rate of $\beta$-cell replication is decreased, but the incidence of apoptosis is increased (74). Analysis of the cell cycle kinetics of $\beta$ cells in situ using immunologic detection of cell cycle-specific proteins suggests that the cell cycle length of $\beta$ cells is prolonged or arrested in low-protein-fed rats, with an extended G1 phase. This is associated with a reduced expression of IGF-II within the pancreatic islets. Thus, IGF-II may not only determine $\beta$-cell mass, but also the phenotype of adult $\beta$ cells. What could depress pancreatic IGF-II expression during IUGR? Perhaps a direct effect of selected amino acids, inasmuch as we have recently shown that supplementation of the pregnant rat given a low-protein diet with taurine can reverse the deficit in pancreatic IGF-II mRNA (75). Another possibility is that a reduced expression of IGF-II mRNA could be due to increased levels of circulating corticosteroid in IUGR.

Glucocorticoids have been shown to decrease the expression of IGF-II and the IGF receptor in late fetal life $(76,77)$, and a neonatal increase in corticosterone may precipitate a decrease in pancreatic IGF-II expression, and a wave of $\beta$-cell apoptosis within islets. In addition, the expression of several IGFBP is under glucocorticoid control (78). Glucocorticoids are also capable of down-regulating $P d x-1$ expression, mediated by a blockade of an enhancer region in the $P d x-1$ promoter that recognizes HNF-3 $\beta$ and BETA-2 (79).

\section{ABNORMAL PANCREATIC DEVELOPMENT IN UTERO AND ADULT DIABETES}

Plasticity exists in the fetal and neonatal pancreas allowing changes in $\beta$-cell number through both $\beta$-cell replication and neogenesis, but later becomes restricted. Consequently, any deficiency in $\beta$-cell mass occurring in utero as a result of either genetic mutations within transcription factors, or maternal malnutrition or placental dysfunction leading to inappropriate expression of transcription or growth factors, will have only a limited opportunity for correction postnatally. In the rat and mouse at least two developmental windows exist in pancreatic ontogeny. The first covers the initial embryogenic process of 
endocrine cell formation, and the subsequent cellular expansion of those islets. Insulin release from the $\beta$ cells within these fetal-type islets is poorly responsive to glucose, with no acute release pharmacokinetics, but is very responsive to amino acids. Shortly after birth a developmental apoptosis appears to delete many of these $\beta$ cells and they are simultaneously replaced with new islets derived from a second wave of neogenesis. The $\beta$-cell population is now sensitive to glucose with acute, first phase insulin release. This developmental change may prepare the animal for postnatal metabolism. Parallel changes may occur in the exocrine pancreas concerning the ontogeny of expression of lipases (80). Early environmental insults may alter the timing or amplitude of developmental changes leaving the individual with a $\beta$-cell population poorly suited both quantitatively and qualitatively for postnatal life, and ultimately leading to glucose intolerance. The finding of a similar developmental apoptosis of $\beta$ cells in the third trimester human fetus (81) would coincide with the acquisition of glucose sensitivity by human fetal $\beta$ cells, the maturation and functional activation of adipocytes, and the laying down of white adipose tissue. Thus, the establishment of postnatal insulin release kinetics and end organ sensitivity may be coordinated events in the third trimester as the human fetus prepares itself for extrauterine life. The precise ontogeny is likely to be controlled by the integrated effects of pancreatic transcription and growth factors whose expression can be modulated by nutritional metabolites or glucocorticoid availability. Abnormal programming of the fetal pancreas could be a major risk factor for adult diabetes.

\section{REFERENCES}

1. Barker DJP 1994 The fetal origins of adult disease. Fetal Mat Med Rev 6:71-80

2. Hales CN, Barker DJ, Clark PM, Cox LJ, Fall C, Osmond C, Winter PD 1991 Feta and infant growth and impaired glucose tolerance at age 64. BMJ 303:1019-1022

3. Hofman PL, Cutfield WS, Robinson EM, Bergman RN, Menon RK, Sperling MA Gluckman PD 1997 Insulin resistance in short children with intrauterine growth retardation. J Clin Endocrinol Metab 82:402-406

4. Duvillie B, Cordonnier C, Deltour L, Dandoy-Dron F, Itier JM, Monthioux E, Jam J, Joshi RL, Bucchini D 1997 Phenotypic alterations in insulin deficient mutant mice. Proc Natl Acad Sci U S A 94:5137-5140

5. Stoffers DA, Zinkin FT, Stanojevik V, Clarke WL, Habener JF 1997 Pancreatic agenesis attributable to a single deletion in the human IPF-1 coding region. Nat Genet $15: 106-110$

6. De Prins F, Van Assche FA 1982 Intrauterine growth retardation and development of endocrine pancreas in experimental rats. Biol Neonate 41:16-21

7. Van Assche FA, De Prins F, Aerts L, Verjans M 1977 The endocrine pancreas in small-for-dates infants. Br J Obstet Gynaecol 84:751-753

8. Garofano A, Czernichow P, Breant B 1997 In utero undernutrition impairs rat beta-cell development. Diabetologia 40:1231-1234

9. Snoeck A, Remacle C, Reusens B, Hoet JJ 1990 Effect of a low protein diet during pregnancy on the fetal rat endocrine pancreas. Biol Neonate 57:107-118

10. Hoet JJ, Dahri S, Reusens B, Remacle C 1994 Do NIDDM and cardiovascular disease originate in utero? In: Baba S, Kaneko T (eds) Diabetes 1994. Elsevier, Amsterdam, pp $62-71$

11. Slack JMW 1995 Developmental biology of the pancreas. Development 121:15691580

12. Golosow N, Goldstein C 1962 Epitheliomesenchymal interaction in pancreatic morphogenesis. Dev Biol 4:242-255

13. Haffen K, Kedinger M, Simon-Assman PM 1989 Cell contact dependent regulation o enterocystic differentiation. In: Lebenthal E (ed) Human Gastrointestinal Development. Raven Press, New York, pp 19-39

14. Wessels NK, Cohen JH 1967 Early pancreas organogenesis: morphogenesis, tissue interactions, and mass effects. Dev Biol 15:237-270

15. Bellusci S, Furuta Y, Rush MG, Henderson R, Winnier G, Hogan BLM 1997 Involvement of Sonic hedgehog (Shh) in mouse embryonic lung growth and morphogenesis. Development 124:53-63

16. Kim SK, Hebrok M, Melton M 1997 Notochord to endoderm signaling is required for pancreas development. Development 124:4243-4252

17. Hebrok M, Kim SG, Douglas AM 1998 Notochord repression of endodermal Sonic hedgehog permits pancreas development. Genes Dev 12:1705-1713
18. Apelqvist A, Ahlgren U, Edlund H 1997 Sonic hedgehog directs specialised mesoderm differentiation in the intestine and pancreas. Curr Biol 7:801-804

19. Teitelman G 1993 On the origin of pancreatic endocrine cells, proliferation and neoplastic transformation. Tumour Biol 14:167-173

20. Herrera P, Huarte J, Sanvito J, Meda P, Orci P, Vassali J 1991 Embryogenesis of the murine pancreas; early expression of pancreatic polypeptide gene. Development 113:1257-1265

21. Herrera P, Huarte J, Zufferey R, Nichols A, Mermillod B, Philippe J, Muniesa P, Sanvito F, Orci L, Vassali JD 1994 Ablation of islet endocrine cells by targeted expression of hormone promoter-driven toxigenes. Proc Natl Acad Sci U S A 91:12999-13003

22. Hill DJ, Hogg J 1991 Growth factor control of pancreatic $\beta$ cell hyperplasia. In: Herington A (ed) Growth Factors in Endocrinology: Clinical Endocrinology Metabolism. Bailliere Tindall, London, pp 689-698

23. Kaung HL 2001994 Growth dynamics of pancreatic islet cell populations during fetal and neonatal development of the rat. Dev Dyn 200:163-175

24. Hellerstrom C, Swenne I, Andersson A 1988 Islet cell replication and diabetes. In: Lefabvre PJ, Pipeleers DG (eds) The Pathology of the Endocrine Pancreas in Diabetes. Springer-Verlag, Heidelberg, pp 141-170

25. Finegood DT, Scaglia L, Bonner-Weir S 1995 Dynamics of $\beta$ cell mass in the growing rat pancreas. Diabetes 44:249-256

26. Scaglia L, Cahill CJ, Finegood DT, Bonner-Weir S 1997 Apoptosis participates in the remodeling of the endocrine pancreas in the neonatal rat. Endocrinology 138:17361741

27. Petrik J, Arany E, McDonald TJ, Hill DJ 1998 Apoptosis in the pancreatic islet cells of the neonatal rat is associated with a reduced expression of insulin-like growth factor II that may at as a survival factor. Endocrinology 139:2994-3004

28. Sander M, German S 1997 The $\beta$ cell transcription factors and development of the pancreas. J Mol Med 75:327-340

29. Offield MF, Jetton TL, Labosky PA, Ray M, Stein RW, Magnuson MA, Hogan BL, Wright CV 1996 PDX-1 is required for pancreatic outgrowth and differentiation of the rostral duodenum. Development 122:983-995

30. Hagenbuche O, Krapp A, Knoffler M, Wellauer P 1997 The bHLH protein p48, a DNA binding subunit of PTF1, acts as a morphogen during pancreas development. Exp Clin Endocrinol Diabetes 105:A9

31. Yi ES, Yin S, Harclerode DL, Bedoya A, Bikhazi NB, Housley RM, Aukerman SL, Morris CF, Pierce GF, Ulich TR 1994 Keratinocyte growth factor induces pancreatic ductal epithelial proliferation. Am J Pathol 145:80-85

32. Nguyen HQ, Danilenko DM, Bucay N, DeRose ML, Van GY, Thomason A, Simonet WS 1996 Expression of keratinocyte growth factor in embryonic liver of transgenic mice causes changes in epithelial growth and differentiation resulting in polycystic kidneys and other organ malformations. Oncogene 12:2109-2119

33. Oberg C, Waltenberger J, Claesson-Welsh L, Welsh M 1994 Expression of protein kinases in islet cells: possible role of the Flk-1 receptor for $\beta$-cell maturation from duct cells. Growth Factors 10:115-126

34. Oberg-Welsh C, Sandler S, Andersson A, Welsh M 1997 Effects of vascular endothelial growth factor on pancreatic duct cell replication and the insulin production of fetal islet-like cell clusters in vitro. Mol Cell Endocrinol 126:125-132

35. Fan L, Iseki S 1998 Immunohistochemical localization of vascular endothelial growth factor in the endocrine glands of the rat. Arch Histol Cytol 61:17-28

36. Kuroda M, Oka T, Oka Y, Yamochi T, Ohtsubo K, Mori S, Watanabe T, Machinami R, Ohnishi S 1995 Colocalization of vascular endothelial growth factor (vascular permeability factor) and insulin in pancreatic islet cells. J Clin Endocrinol Metab 180:3196-3200

37. Sosa-Pineda B, Chowdhury K, Torres M, Oliver G, Gruss P 1997 The Pax-4 gene is essential for the differentiation of insulin-producing $\beta$-cells in mammalian pancreas Nature 386:399-402

38. Edlund H 1998 Transcribing pancreas. Diabetes 47:1817-1822

39. St-Onge L, Sosa-Pineda B, Chowdhury K, Mansouri A, Gruss P 1997 Pax6 is required for differentiation of glucagon-producing cells in mouse pancreas. Nature 387:406-408

40. Sander M, Neubuser A, Kalamaras J, Ee HC, Martin G, German MS 1997 Genetic analysis reveals that Pax6 is required for normal transcription of pancreatic hormone genes and islet development. Genes Dev 11:1662-1673

41. Hogg J, Hill DJ, Han VKM 1994 The ontogeny of insulin-like growth factor (IGF) and IGF binding protein gene expression in the rat pancreas. J Mol Endocrinol $13 \cdot 49-58$

42. Hill DJ, Hogg J, Petrik J, Arany E, Han VKM 1999 Cellular distribution and ontogeny of insulin-like growth factors (IGFs) and IGF binding protein messenger RNAs and peptides in developing rat pancreas. J Endocrinol 160:305-317

43. Han VKM, Lund PK, Lee DC, D'Ercole AJ 1988 Expression of somatomedin/insulinlike growth factor messenger ribonucleic acids in the human fetus: identification, characterization and tissue distribution. J Clin Endocrinol Metab 66:422-429

44. Hogg J, Han VKM, Clemmons DR, Hill DJ 1993 Interactions of glucose, insulin-like growth factors (IGFs) and IGF binding proteins in the regulation of DNA synthesis by isolated fetal rat islets of Langerhans. J Endocrinol 138:401-412

45. Swenne I, Hill DJ, Strain AJ, Milner RDG 1987 Growth hormone regulation of somatomedin-C/insulin-like growth factor I production and DNA replication in fetal rat islets in tissue culture. Diabetes 36:288-294

46. Van Schravendijk CF, Foriers A, Van Den Brande JL, Pipeleers DG 1987 Evidence for the presence of type I insulin-like growth factor receptors on rat pancreatic A and B cells. Endocrinology 121:1784-1788

47. Petrik J, Pell JM, Arany E, McDonald TJ, Dean WL, Reik W, Hill DJ 1999 Overexpression of insulin-like growth factor-II in transgenic mice is associated with pancreatic islet cell hyperplasia. Endocrinology 140:2353-2363 
48. D'Mello SR, Galli C, Ciotti T, Calissano P 1993 Induction of apoptosis in cerebellar granule neurons by low potassium: inhibition of death by insulin-like growth factor- 1 and cAMP. Proc Nat Acad Sci U S A 90:10989-10993

49. Geier A, Haimshon M, Beery R, Lunenfeld B 1992 Insulin-like growth factor-I inhibits cell death induced by cycloheximide in MCF-7 cells-a model system for analyzing control of cell death. In Vitro Cell Dev Biol Anim 28A:725-729

50. Wright NM, Metzger DL, Borowitz SM, Clarke WL 1993 Permanent neonatal diabetes mellitus and pancreatic exocrine insufficiency resulting from congenital pancreatic agenesis. Am J Dis Child 147:607-609

51. Voldsgaard P, Kryger Baggesen N, Lisse I 1994 Agenesis of pancreas. Acta Paediatr 83:791-793

52. Dourov N, Buyl-Strouvens ML 1969 Agenesie du pancreas. Observation anatomoclinique d'un cas de diabete sucre, avec steatorrhee et hypotrophie, chez un nouveaune. Arch Franc Pediatr 26:641-650

53. Howard CP, Go VL, Infante AJ, Perrault J, Gerich JE, Haymond MW 1980 Long-term survival in a case of functional pancreatic agenesis. J Pediatr 97:786-789

54. Velho G, Froguel P 1998 Genetic, metabolic and clinical characteristics of maturity onset diabetes of the young. Eur J Endocrinol 138:233-239

55. Yamagata K, Furuta H, Oda N, Kaisaki PJ, Menzel S, Cox NJ, Fajans SS, Signorin S, Stoffel M, Bell GI 1996 Mutations in the hepatocyte nuclear factor 4 alpha gene in maturity-onset diabetes of the young (MODY1). Nature 384:468-470

56. Froguel P, Vaxillaire M, Sun F, Velho G, Zouali H, Butel MO, Lesage S, Vionnet N, Clément K, Fougerousse F, et al 1992 Close linkage of glucokinase locus on chromosome $7 \mathrm{p}$ to early-onset non-insulin-dependent diabetes mellitus. Nature 356:162-164

57. Velho G, Blanché H, Vaxillaire M, Bellanné Chantelot C, Pardini VC, Timsit J, Passa P, Deschamps I, Robert JJ, Weber IT, Marotta D, Pilkis SJ, Lipkind GM, Bell GI, Froguel P 1997 Identification of 14 new glucokinase mutations and description of the clinical profile of 42 MODY-2 families. Diabetologia 40:217-224

58. Vaxillaire M, Rouard M, Yamagata K, Oda N, Kaisaki PJ, Boriraj VV, Chevre JC, Boccio V, Cox RD, Lathrop GM, Dussoix P, Philippe J, Timsit J, Charpentier G, Velho G, Bell GI, Froguel P 1997 Identification of nine novel mutations in the hepatocyte nuclear factor 1 alpha gene associated with maturity onset diabetes of the young (MODY 3). Human Mol Genet 6:583-586

59. Stoffers DA, Ferrer J, Clarke WL, Habener JF 1997 Early-onset type 2 diabetes mellitus (MODY4) linked to IPF1. Nat Genet 17:138-139

60. Ahlgren U, Jonsson J, Jonsson L, Simu K, Edlund H $1998 \beta$-cell-specific inactivation of the mouse Ipf1/Pdx 1 gene results in loss of the $\beta$-cell phenotype and maturity onset diabetes. Genes Dev 12:1763-1768

61. Byrne MM, Sturis J, Menzel S, Yamagata K, Fajans SS, Dronsfield MJ, Bain SC, Hattersley AT, Velho G, Froguel P, Bell GI, Polonsky KS 1996 Altered insulin secretory responses to glucose in diabetic and nondiabetic subjects with mutations in the diabetes mellitus susceptibility gene MODY on chromosome 12. Diabetes 45:1503-1510

62. Dukes ID, Sreenan S, Roe MW, Levissetti M, Zhou YP, Ostrega D, Bell GI, Pontoglio M, Yaniv M, Philipson L, Polonsky KS 1998 Defective pancreatic beta-cell glycolytic signaling in hepatocyte nuclear factor-1 alpha deficient mice. J Biol Chem 273:24457-24464

63. Herman WH, Fajans SS, Ortiz FJ, Smith MJ, Sturis J, Bell GI, Polonsky KS, Halter JB 1994 Abnormal insulin secretion, not insulin resistance, is the genetic or primary defect of MODY in the RW pedigree. Diabetes 43:40-46

64. Byrne MM, Sturis J, Fajans SS, Ortiz FJ, Stoltz A, Stoffel M, Smith MJ, Bell GI, Halter JB, Polonsky KS 1995 Altered secretory responses to glucose in subjects with a mutation in the MODY1 gene on chromosome 20. Diabetes 44:699-704

65. MacFarlane WM, Read ML, Gilligan M, Bujalska I, Docherty K 1994 Glucose modulates the binding activity of the beta-cell transcription factor IUF1 in a phosphorylation-dependent manner. Biochem J 303:625-631
66. Jonas J, Sharma A, Ilkova H, Patane G, Bonner-Weir S, Weir G 1998 Pdx-1 and HNF mRNA levels are reduced in islets from hyperglycemic $90 \%$ pancreatectomized rats [abstract 1004]. Proceedings of the 58th Annual Meeting of the American Diabetes Association, Chicago.

67. Gremlich S, Bonny C, Waeber G, Thorens B 1997 Fatty acids induce a decrease in islet/duedenum homeobox-1 (IDX-1) expression in adult rat pancreatic islets, and a parallel decrease in GLUT2, glucokinase, insulin and somatostatin gene expression. Exp Clin Endocrinol Diabetes 105:A22

68. Petersen HV, Peshavaria M, Pedersen AA, Philippe J, Stein R, Madsen OD, Serup P 1998 Glucose stimulates the activation domain potential of the PDX-1 homeodomain transcription factor. FEBS Lett 431:362-366

69. Zangen DH, Bonner-Weir S, Lee CH, Latimer JB, Miller CP, Habener JF, Weir GC 1997 Reduced insulin, GLUT2, and IDX-1 in $\beta$-cells after partial pancreatectomy. Diabetes 46:258-264

70. Hill DJ, Fekete M, Milner RDG, De Prins F, Van Assche A 1983 Reduced plasma somatomedin activity during experimental growth retardation in the fetal and neonatal rat. In: Spencer EM (ed) Insulin-like Growth Factors/Somatomedins. Basic Chemistry, Biology, Clinical Importance.Walter de Gruyter, Berlin, pp 345-352

71. Hill DJ, Sheffrin RA, Milner RDG 1982 Raised plasma somatomedin activity and cartilage metabolic activity ${ }^{35} \mathrm{~S}$ sulphate uptake in vitro) in the fetus of the subdiabetic pregnant rat. Diabetologia 23:270-274

72. De Prins FA, Hill DJ, Fekete M, Robsen DJ, Fieller NRJ, Van Assche FA, Milner RDG 1984 Reduced plasma somatomedin activity and sulphate incorporation by costal cartilage in vitro during experimental growth retardation in the fetal rat. Pediatr Res 18:1100-1104

73. Verhaeghe J, Van Bree R, Van Herck E, Laureys J, Bouillon R, Van Assche A 1993 C-peptide, insulin-like growth factors I and II, and insulin-like growth factor binding protein-1 in umbilical cord serum: correlations with birth weight. Am J Obstet Gynecol 169:89-97

74. Petrik J, Reusens B, Arany E, Remacle C, Hoet JJ, Hill DJ 1999 A low protein diet alters the balance of islet cell replication and apoptosis in the fetal and neonatal rat, and is associated with a reduced pancreatic expression of insulin-like growth factor-II. Endocrinology 140:4861-4873

75. Boujendar S, Reusens B, Hill DJ, Hoet JJ, Remacle C 1999 Supplementation of the low protein diet of the mother restores a normal development of the endocrine pancreas in the offspring. 2nd World Congress on Prevention of Diabetes and Its Complications, Fiuggi, Rome, Italy, p 24

76. Li J, Saunders JC, Fowden AL, Dauncey MJ, Gilmour RS 1998 Transcriptional regulation of insulin-like growth factor-II gene expression by cortisol in fetal sheep during late gestation. J Biol Chem 273:10586-10593

77. Price WA, Stiles AD, Moats-Staats BM, D'Ercole AJ 1992 Gene expression of the insulin- like growth factors (IGFs), the type 1 IGF receptor, and IGF binding proteins in dexamethasone-induced fetal growth retardation. Endocrinology 130:1424-1432

78. McCusker RH, Clemmons DR 1992 The insulin-like growth factor binding proteins: structure and biological functions. In: Schofield PN (ed) The Insulin-Like Growth Factors, Structure and Biological Functions. Oxford University Press, Oxford, pp $110-150$

79. Sharma S, Jhala US, Johnson T, Ferreri K, Leonard J, Montminy M 1997 Hormonal regulation of an islet-specific enhancer in the pancreatic homeobox gene STF-1. Mol Cell Biol 17:2598-2604

80. Yang Y, Sanchez D, Figarella C, Lowe M 2000 Discoordinate expression of pancreatic lipase and two related proteins in the human fetal pancreas. Pediatr Res 47:184-188

81. Tornehave D, Larsson L-I 1997 Presence of Bcl-X during development of the human fetal and rat neonatal endocrine pancreas: correlation to programmed cell death. Exp Clin Endocrinol Diabetes 105:A27 